\title{
Resveratrol promotes regression of renal carcinoma cells via a renin-angiotensin system suppression-dependent mechanism
}

\author{
JIANCHANG LI* , MINGNING QIU* , LIEQIAN CHEN, LEI LIU, GUOBIN TAN and JIANJUN LIU \\ Laboratory of Urology, Guangdong Medical University, Zhanjiang, Guangdong 524001, P.R. China
}

Received July 2, 2015; Accepted October 11, 2016

DOI: $10.3892 / \mathrm{ol} .2016 .5519$

\begin{abstract}
The aim of the present study was to investigate the effect of resveratrol on renal carcinoma cells and explore possible renin-angiotensin system-associated mechanisms. Subsequent to resveratrol treatment, the cell viability, apoptosis rate, cytotoxicity levels, caspase 3/7 activity and the levels of angiotensin II (AngII), AngII type 1 receptor (AT1R), vascular endothelial growth factor (VEGF) and cyclooxygenase-2 (COX-2) were evaluated in renal carcinoma cells. The effects of AngII, AT1R, VEGF and COX-2 on resveratrol-induced cell growth inhibition and apoptosis were also examined. The results indicated that resveratrol treatment may suppress growth, induce apoptosis, and decrease AngII, AT1R, VEGF and COX-2 levels in renal carcinoma ACHN and A498 cells. In addition, resveratrol-induced cell growth suppression and apoptosis were reversed when co-culturing with AT1R or VEGF. Thus, resveratrol may suppress renal carcinoma cell proliferation and induce apoptosis via an AT1R/VEGF pathway.
\end{abstract}

\section{Introduction}

Resveratrol (molecular formula, $\mathrm{C}_{14} \mathrm{H}_{12} \mathrm{O}_{3}$; CAS number, 501-36-0) is a non-toxic phytoalexin antioxidant and an effective anticancer compound that can be extracted from grapes, red wines, berries and peanuts (1), which imparts cancer chemopreventive and therapeutic responses $(2,3)$. It is suggested to have potent antitumor properties against numerous human cancers $(4,5)$. The renin-angiotensin system (RAS) is classically described as an important endocrine system that regulates blood pressure and electrolyte balance. Studies have demonstrated that RAS may be

Correspondence to: Dr Jianjun Liu, Laboratory of Urology, Guangdong Medical University, 57 Renmin Road, Zhanjiang, Guangdong 524001, P.R. China

E-mail: jianjunliulab@163.com

*Contributed equally

Key words: resveratrol, renal carcinoma cells, cell proliferation, apoptosis, renin-angiotensin system involved in numerous pathophysiological processes, such as maintaining blood pressure/blood volume homeostasis and ion-fluid balance, phylogenetic advancement, growth promotion and angiogenesis, ontogeny and phylogeny (6). RAS is also involved in several cancers, including glioblastoma multiform (7), and bladder (8) and renal (9) cancers. Previous studies have suggested that resveratrol may play anticancer roles via a RAS-dependent pathway, such as in renal (10) and bladder (8) cancer cells. Angiotensin II (AngII), which is known to be the main effector of the RAS pathway, has an important role in regulating cancer inflammation and tumor angiogenesis (11). The majority of AngII effects are mediated by 2 specific receptors subtypes, consisting of AngII type 1 receptor (AT1R) and AngII type 2 receptor (AT2R) (12), which are detected in astrocytomas (13), esophageal squamous cell carcinoma (14) and renal clear cell carcinoma (15). AT1R-mediated AngII activity plays a central role in mediating the majority of the actions of the RAS pathway (16). Vascular endothelial growth factor (VEGF) and epidermal growth factor receptor (EGFR) are important molecules in tumor-associated angiogenesis, as they activate endothelial cell metastasis and increase vascular permeability (17-19). Inhibition of VEGF suppresses tumor angiogenesis and tumor growth in vivo (20). As an important downstream regulator in RAS, VEGF is reported to be induced by AngII, by binding AT1R in pancreatic cancer cells (21). Cyclooxygenase-2 (COX-2) is a key enzyme involved in carcinogenesis and tumor progression, particularly in neoangiogenesis and lymphovascular invasion (22-24), and has also been detected as upregulated through mechanisms distinct from the VEGF axis (25-27). In the present study, the suppression of proliferation and induction of apoptosis by resveratrol was investigated in renal carcinoma cell lines. The levels of the 4 important factors in RAS, consisting of AngII, AT1R, VEGF and COX-2 were examined, and the potential mechanisms were analyzed.

\section{Materials and methods}

Cell culture and resveratrol treatment. Human renal carcinoma ACHN and A498 cell lines were purchased from Guangzhou Jennio Biological Technology Co., Ltd (Guangzhou, China). ACHN cells were cultured in high glucose Dulbecco's modified Eagle medium (Gibco, Thermo Fisher Scientific, Inc., Waltham, MA, USA) supplemented with $10 \%$ 
(v/v) fetal bovine serum (FBS; Gibco, Thermo Fisher Scientific, Inc.). A498 cells were cultured in RPMI-1640 medium (Gibco; Thermo Fisher Scientific, Inc.) supplemented with $10 \%$ (v/v) FBS. The two cell lines were cultured at $37^{\circ} \mathrm{C}$ in a $5 \%$ humidified $\mathrm{CO}_{2}$ atmosphere. Resveratrol was purchased from Sigma-Aldrich; Merck Millipore (Darmstadt, Germany). Resveratrol was dissolved in DMSO to create a stock solution at a concentration of $100 \mathrm{mM}$, which was subsequently diluted in culture medium to the desired concentration for experiments. DMSO was used as the vehicle control.

Enzyme-linked immunosorbent assay (ELISA). Subsequent to ACHN and A498 cells being treated with resveratrol, the medium was collected by centrifugation at $400 \mathrm{x} g$ for $15 \mathrm{~min}$ at $4^{\circ} \mathrm{C}$, and the liquid supernatant was stored at $-80^{\circ} \mathrm{C}$ until ELISA. ACHN and A498 cells were lysed with sodium dodecyl sulfate (SDS) lysis buffer (Beyotime Institute of Biotechnology, Shanghai, China), and total proteins were extracted at $4^{\circ} \mathrm{C}$. The concentrations of AngII, AT1R, VEGF and COX-2 in the culture medium and cells were determined using a human AngII ELISA kit (catalogue no., ml003766; Shanghai Enzyme-linked Biotechnology Co., Ltd., Shanghai, China), an AT1R ELISA kit (catalogue no., ml006788; Shanghai Enzyme-linked Biotechnology Co., Ltd.), a VEGF ELISA kit (catalogue no., ml009877; Shanghai Enzyme-linked Biotechnology Co., Ltd.) and a COX-2 ELISA Kit (catalogue no., m1006532; Shanghai Enzyme-linked Biotechnology Co., Ltd.) in accordance with the manufacturers' protocols.

Cell proliferation assay. Effects of resveratrol treatment on the cell proliferation of renal carcinoma cells were detected by Cell Counting Kit-8 (CCK-8; Dojindo Molecular Technologies, Inc., Mashikimachi, Kumamoto, Japan) assay. ACHN and A498 cells were seeded in 96-well plates (Corning Incorporated, Corning, NY, USA) at a density of $5 \times 10^{3}$ cells per well with $100 \mu \mathrm{l}$ culture medium. Subsequent to allowing $24 \mathrm{~h}$ for adhering, resveratrol was added at varying concentrations for 12, 24 and $48 \mathrm{~h}$. The culture medium was then removed and replaced with $100 \mu \mathrm{l}$ medium containing CCK-8 reagent $(10 \mu \mathrm{l}$; Dojindo Molecular Technologies, Inc.) in each well. The plates were incubated at $37^{\circ} \mathrm{C}$ for $2 \mathrm{~h}$. Absorbance at $450 \mathrm{~nm}$ was recorded using a spectrophotometer (EnSpire 2300 Multilabel Reader; PerkinElmer, Waltham, MA, USA).

Apoptosis detection. Apoptosis cells were quantified using a fluorescein isothiocyanate Annexin V Apoptosis Detection Kit (BD Pharmingen, San Diego, CA, USA) according to the manufacturer's protocol. Cells were cultured in 6-well plates at a density of $1 \times 10^{5}$ cells per well. Following $24 \mathrm{~h}$ growth, cells were treated with various resveratrol concentrations and harvested for the apoptosis assay. Untreated cells were used as a negative control.

Colony formation assay. Cells $\left(1 \times 10^{3}\right.$ cells per well) were seeded into 6 -well plates subsequent to $6 \mathrm{~h}$-treatment with various concentrations of resveratrol and were cultured for 2 weeks. The number of colonies formed was counted subsequent to cells being fixed with $4 \%$ paraformaldehyde, and stained with a crystal violet staining solution (Beyotime Institute of Biotechnology).
Caspase-Glo $3 / 7$ assays. Cells $\left(5 \times 10^{3}\right.$ cells per well) were seeded onto 96 -well plates and exposed to different concentrations of resveratrol. Equal volume of Caspase-Glo 3/7 reagent was subsequently added into each well and incubated for $30 \mathrm{~min}$ at room temperature in the dark. The luminescence was determined using a luminometer (Berthold Sirius L; Titertek-Berthold, Pforzheim, Germany).

Cytotoxicity assay. The cytotoxicity of resveratrol was assessed using a lactate dehydrogenase (LDH) Cytotoxicity Assay kit (Beyotime Institute of Biotechnology) according to the manufacturer's protocol. Cells were cultured in 96-well plates (Corning Incorporated) and then treated with resveratrol for $24 \mathrm{~h}$. The medium was collected by centrifugation at $400 \mathrm{x} g$ for $5 \mathrm{~min}$. Supernatant $(120 \mu \mathrm{l} /$ well) was transferred into another 96 -well plate and $60 \mu \mathrm{l} \mathrm{LDH}$ detection reagent was added to each well, and then incubated for $30 \mathrm{~min}$ at room temperature in the dark. Absorbance was recorded at $490 \mathrm{~nm}$ with a spectrophotometer (EnSpire 2300 Multilabel Reader; PerkinElmer).

Western blot analysis. The expression of the apoptosis-associated proteins caspase 9, B-cell lymphoma 2 (Bcl-2) and Bcl-2-like protein 4 (Bax) were detected in renal carcinoma cells. Cells were lysed with radioimmunoprecipitation assay buffer (Beyotime Institute of Biotechnology) and then total proteins were extracted at $4^{\circ} \mathrm{C}$. Proteins were separated by SDS-polyacrylamide gel electrophoresis and transferred onto a polyvinylidene fluoride membrane (EMD Millipore, Billerica, MA, USA). Membranes were then blocked using 5\% non-fat milk in Tris-buffered saline and Tween 20 (TBS-T) at room temperature for $1 \mathrm{~h}$, and the membranes were then probed with rabbit anti-human caspase 9 (catalog no., 9502; dilution, 1:1,000; Cell Signaling Technology, Inc., Danvers, MA, USA), Bax (catalog no., 2772; dilution, 1:1,000; Cell Signaling Technology, Inc.) and Bcl-2 rabbit monoclonal antibodies (catalog no., 2876; dilution, 1:1000; Cell Signaling Technology, Inc.). The membranes were probed with a rabbit anti-human GAPDH polyclonal antibody (catalog no., ab37168; dilution, 1:100,000; Abcam, Cambridge, UK) as a loading control. The membranes were washed 3 times with TBS-T for 5 min each time and incubated for $1.5 \mathrm{~h}$ with a horseradish peroxidase-conjugated goat anti-rabbit secondary antibody (catalog no., E030120; dilution, 1:10,000; EarthOx Life Sciences, Millbrae, CA, USA).

Statistical analysis. ELISA, colony formation and Caspase-Glo 3/7 assays were repeated 3 times; CCK-8 and cytotoxicity assays were performed 4 times. One-way analysis of variance (SPSS 18.0; SPSS, Inc., Chicago, IL, USA) and Student's $t$-test (Microsoft Excel; Redmond, WA, USA) were used to evaluate the differences between 2 groups of data in all the experiments. All data were presented as the mean \pm standard deviation (SD). $\mathrm{P}<0.05$ was considered to indicate a statistically significant difference and $\mathrm{P}<0.01$ was considered to indicate an extremely significant difference.

\section{Results}

Resveratrol suppressed growth of renal carcinoma cells. To determine the effect of resveratrol on cell proliferation in 
A
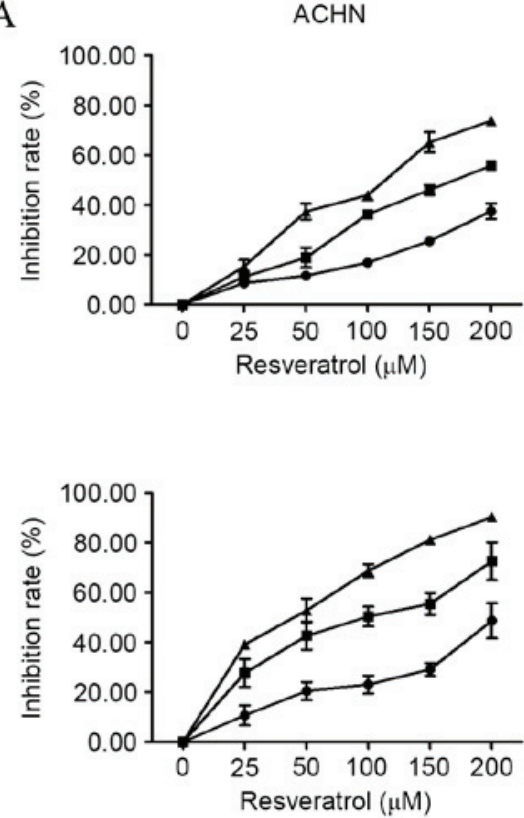

$\mathrm{C}$

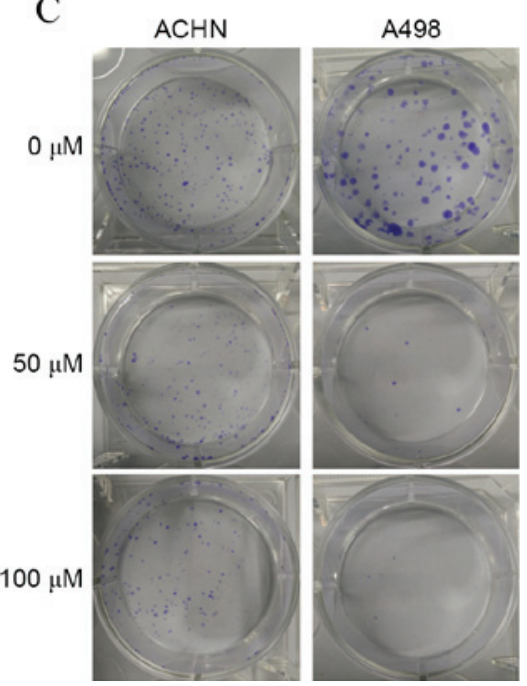

B

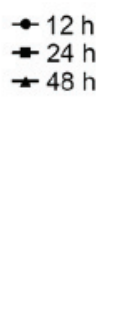

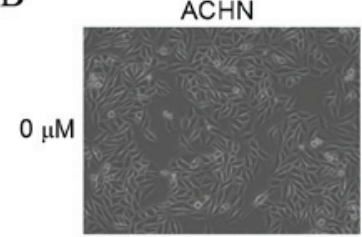

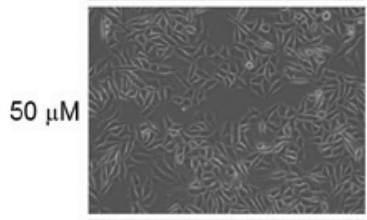

$-12 h$
$-24 h$
$+48 h$
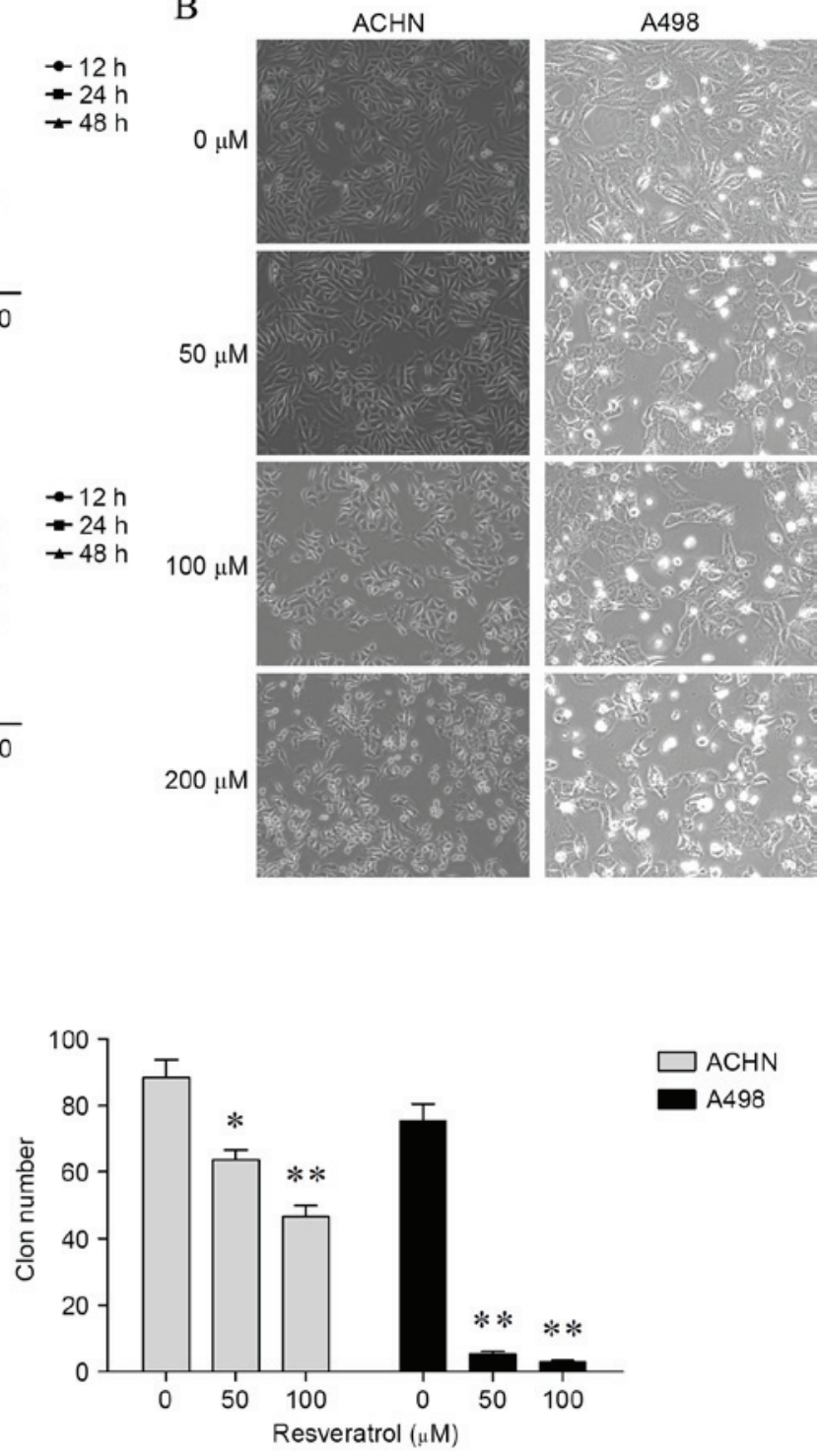

$\mathrm{ACHN}$

A498

Figure 1. Resveratrol suppressed renal carcinoma cell proliferation. (A) Cell growth, as detected by Cell Counting Kit-8 assay, was suppressed in a dose- and time-dependent manner subsequent to resveratrol treatment. (B) Resveratrol inhibited proliferation in ACHN and A498 cells at 24 h, which was visualized by microscopy (magnification, x100). (C) Representative pictures and quantification of resveratrol-induced colony formation suppression in renal carcinoma cells followed $6 \mathrm{~h}$ resveratrol treatment. ${ }^{*} \mathrm{P}<0.05$ and ${ }^{* *} \mathrm{P}<0.01$, experimental vs. control groups.

renal carcinoma cells, the present study firstly determined cell viability by CCK-8 assay. As shown in Fig. 1A, renal carcinoma cells treated with 25, 50, 100, 150 and 200 resveratrol for 12,24 and $48 \mathrm{~h}$, cell viability was significantly inhibited in a dose- and time-dependent manner compared with cells treated with $0 \mu \mathrm{M}$ resveratrol [ACHN cells, $\mathrm{P}<0.001$ for all concentrations at 12, 24 and $48 \mathrm{~h}$; A498 cells, $\mathrm{P}<0.001$ for all concentrations at 12,24 and $48 \mathrm{~h}$, with the exception of $25 \mu \mathrm{M}$ for $12 \mathrm{~h}(\mathrm{P}=0.0017)]$. For morphology analysis, untreated renal carcinoma cells grew well, whereas the cells treated with resveratrol were distorted in shape and became round and underwent apoptosis (Fig. 1B). Furthermore, following $6 \mathrm{~h}$ of treatment with resveratrol, colony formation assay was performed and revealed a marked decrease in colony formation compared to the control group $(\mathrm{ACHN}$ cells, $\mathrm{P}=0.0158$ by $50 \mu \mathrm{M}$ and $\mathrm{P}=0.0026$ by $100 \mu \mathrm{M}$; $\mathrm{A} 498$ cells, $\mathrm{P}=0.0002$ by $50 \mu \mathrm{M}$ and $\mathrm{P}=0.0002$ by $100 \mu \mathrm{M}$; Fig. 1C).
Resveratrol induced apoptosis in renal carcinoma cells. To illustrate the functions of resveratrol on apoptosis in renal carcinoma cells, cytotoxicity, caspase $3 / 7$ activity, cell apoptosis and expression of caspase 9, Bcl-2 and Bax were determined. It was found that resveratrol significantly increased cytotoxicity (ACHN cells: $25 \mu \mathrm{M}, \mathrm{P}<0.001 ; 50 \mu \mathrm{M}, \mathrm{P}=0.0036 ; 100 \mu \mathrm{M}$, $\mathrm{P}=0.0314 ; 150 \mu \mathrm{M}, \mathrm{P}=0.0034$; and $200 \mu \mathrm{M}, \mathrm{P}=0.0007 ; \mathrm{A} 498$ cells: $25 \mu \mathrm{M}, \mathrm{P}<0.001 ; 50 \mu \mathrm{M}, \mathrm{P}=0.0041 ; 100 \mu \mathrm{M}, \mathrm{P}=0.0327$; $150 \mu \mathrm{M}, \mathrm{P}=0.0032$; and $200 \mu \mathrm{M} \mathrm{P}=0.0005$; Fig. $2 \mathrm{~A}$ ) and caspase 3/7 activity (ACHN cells, $\mathrm{P}<0.001$ for 50,100 and $200 \mu \mathrm{M}$; A498 cells, $\mathrm{P}<0.001$ for 50,100 and $200 \mu \mathrm{M}$; Fig. $2 \mathrm{~B}$ ) in renal cancer cells compared with cells treated with $0 \mu \mathrm{M}$ resveratrol. Results of flow cytometry assay revealed that subsequent to $24 \mathrm{~h}$ of treatment with resveratrol, apoptosis was induced in renal carcinoma cells (Fig. 2C). In addition, resveratrol was shown to upregulate cleaved-caspase 9 and Bax levels and downregulate Bcl-2 level in the two cell lines (Fig. 2D). 

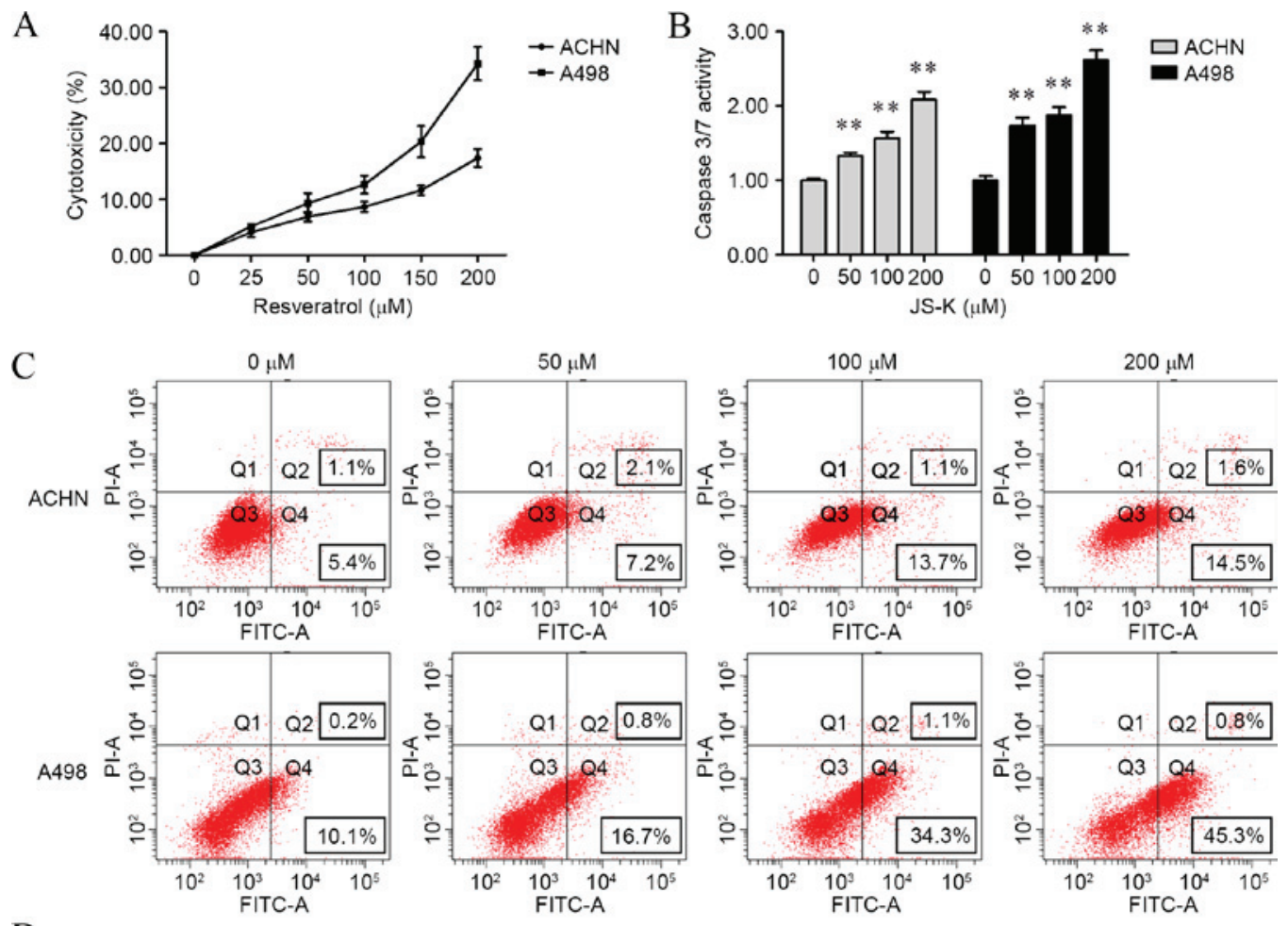

D
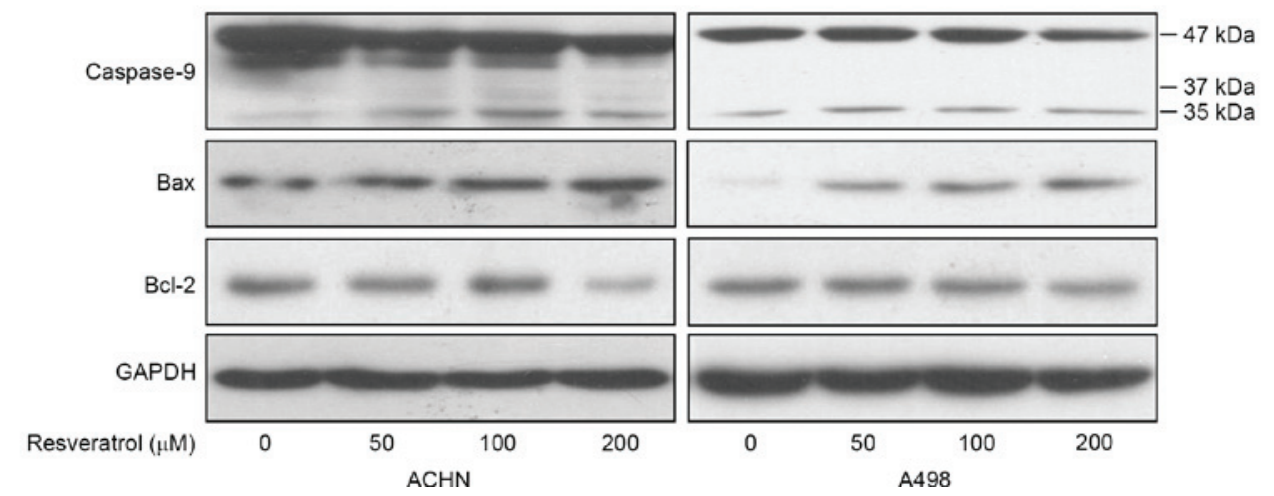

Figure 2. Resveratrol induced apoptosis in renal carcinoma cells. (A) Cytotoxicity of resveratrol was determined by a lactate dehydrogenase assay. (B) Caspase 3/7 activity subsequent to resveratrol treatment was determined by a Caspase-Glo 3/7 assay. (C) Resveratrol-induced apoptosis in renal carcinoma cells with different concentrations $(0,50,100$ and $200 \mu \mathrm{M})$ for $24 \mathrm{~h}$, which was analyzed by flow cytometry. (D) Cells were treated with resveratrol $(0,50,100$ and $200 \mu \mathrm{M}$ ) for $24 \mathrm{~h}$, and the levels of caspase 9, Bax and Bcl-2 were detected by western blotting. The data showed that resveratrol regulated apoptotic proteins in renal carcinoma cells in a dose-dependent manner. ${ }^{* * *} \mathrm{P}<0.01$, experimental vs. control groups. JS-K, $O^{2}-(2,4-$ dinitrophenyl)1-[(4-ethoxyxarbonyl) piperazin-1-yl]diazen-1-ium-1,2-diolate; FITC, fluorescein isothiocyanate; Bcl-2, B-cell lymphoma 2; Bax, bcl-2-like protein 4; GAPDH, glyceraldehyde 3-phosphate dehydrogenase.

Resveratrol suppressed AngII, ATIR, VEGF and COX-2 in a dose-dependent manner. To confirm whether AngII, AT1R, VEGF and COX-2 levels would be affected by resveratrol, $\mathrm{ACHN}$ and A498 cells were treated with various concentrations of resveratrol for $24 \mathrm{~h}$, and the levels of AngII, AT1R, VEGF and COX-2 in cells and culture medium were determined. As shown in Figs. 3 and 4, levels of AngII (ACHN cells: $50 \mu \mathrm{M}, \mathrm{P}=0.0086 ; 100 \mu \mathrm{M}, \mathrm{P}<0.001$; and $200 \mu \mathrm{M}$, $\mathrm{P}<0.001$; A498 cells: $50 \mu \mathrm{M}, \mathrm{P}=0.0015 ; 100 \mu \mathrm{M}, \mathrm{P}=0.0002$; and $200 \mu \mathrm{M}, \mathrm{P}=0.0003$; culture medium of $\mathrm{ACHN}$ cells: $50 \mu \mathrm{M}, \mathrm{P}=0.0113 ; 100 \mu \mathrm{M}, \mathrm{P}=0.0031$; and $200 \mu \mathrm{M}, \mathrm{P}=0.0026$; culture medium for A498 cells: $50 \mu \mathrm{M}, \mathrm{P}=0.0246 ; 100 \mu \mathrm{M}$, $\mathrm{P}=0.0015$ and $200 \mu \mathrm{M}, \mathrm{P}=0.0007$; Figs. 3A and 4A), AT1R (ACHN cells: $50 \mu \mathrm{M}, \mathrm{P}=0.0317 ; 100 \mu \mathrm{M}, \mathrm{P}=0.0033$; and $200 \mu \mathrm{M}, \mathrm{P}=0.0013$; A498 cells: $50 \mu \mathrm{M}, \mathrm{P}=0.0221 ; 100 \mu \mathrm{M}$, $\mathrm{P}=0.0031$; and $200 \mu \mathrm{M}, \mathrm{P}=0.0023$; culture medium for $\mathrm{ACHN}$ cells: $50 \mu \mathrm{M}, 0.0110 ; 100 \mu \mathrm{M}, 0.0011$; and $200 \mu \mathrm{M}, 0.0008$; culture medium for A498 cells: $50 \mu \mathrm{M}, \mathrm{P}=0.0340 ; 100 \mu \mathrm{M}$, $\mathrm{P}=0.0019$; and $200 \mu \mathrm{M}, \mathrm{P}=0.0016$; Figs. $3 \mathrm{~B}$ and $4 \mathrm{~B})$, VEGF (ACHN cells: $50 \mu \mathrm{M}, \mathrm{P}=0.0062 ; 100 \mu \mathrm{M}, \mathrm{P}=0.0068$; and $200 \mu \mathrm{M}, \mathrm{P}=0.0024$; A498 cells: $50 \mu \mathrm{M}, \mathrm{P}=0.0221 ; 100 \mu \mathrm{M}$, $\mathrm{P}=0.0259$; and $200 \mu \mathrm{M}, 0.0045$; culture medium for ACHN cells: $50 \mu \mathrm{M}, \mathrm{P}=0.0341 ; 100 \mu \mathrm{M}, \mathrm{P}=0.0012$; and $200 \mu \mathrm{M}$, $\mathrm{P}=0.0003$; culture medium for $\mathrm{A} 498$ cells: $100 \mu \mathrm{M}, 0.0090$; and $200 \mu \mathrm{M}, 0.0056$; Figs. 3C and 4C) and COX-2 (ACHN cells: $100 \mu \mathrm{M}, 0.0246$; and $200 \mu \mathrm{M}, 0.0138$; A498 cells: $100 \mu \mathrm{M}, 0.0398$; and $200 \mu \mathrm{M}, 0.0259$; culture medium for ACHN cells: $50 \mu \mathrm{M}, 0.0406$; $100 \mu \mathrm{M}, 0.0097$; and $200 \mu \mathrm{M}$, 0.0056; culture medium for A498 cells: $100 \mu \mathrm{M}, 0.0065$; and $200 \mu \mathrm{M}, 0.0061$; Figs. 3D and 4D) were significantly decreased in the two cell lines and culture mediums in a dose-dependent manner compared with cells treated with $0 \mu \mathrm{M}$ resveratrol. 
A

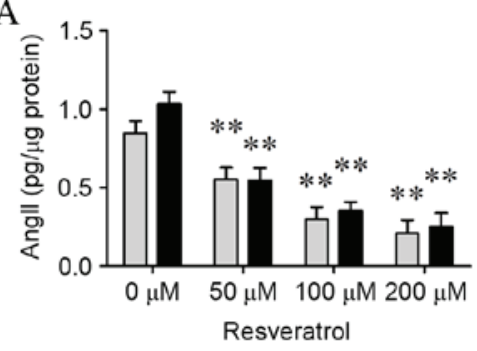

$\mathrm{C}$

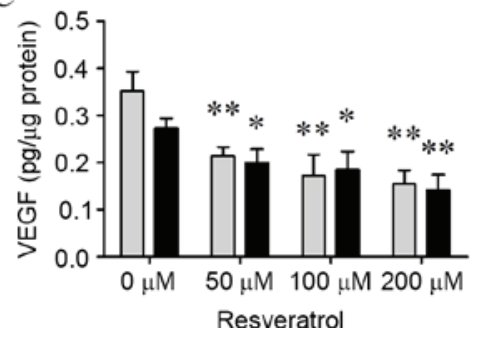

$\mathrm{B}$

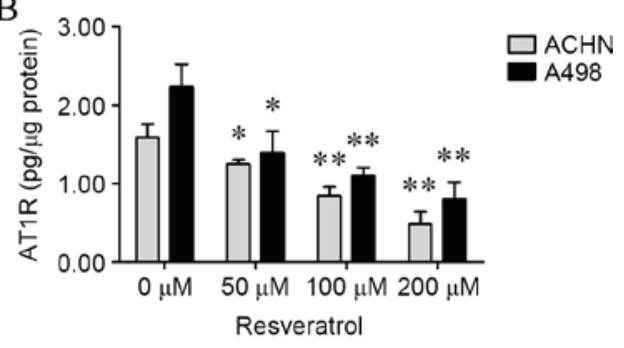

D

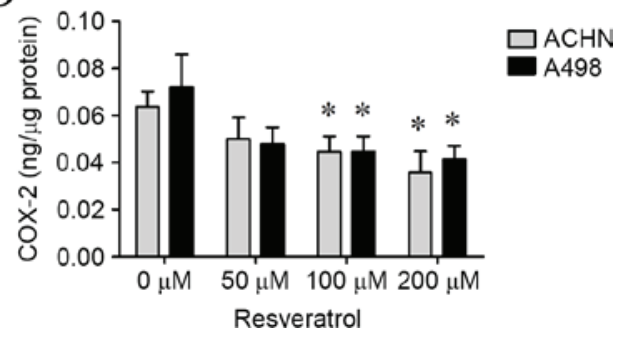

Figure 3. Resveratrol suppressed intracellular AngII, AT1R, VEGF and COX-2 levels in a dose-dependent manner. Subsequent to renal carcinoma cells being treated with resveratrol $(0,50,100$ and $200 \mu \mathrm{M})$ for $24 \mathrm{~h}$, the intracellular levels of (A) AngII, (B) AT1R, (C) VEGF and (D) COX-2 were determined. ${ }^{*} \mathrm{P}<0.05$ and $^{* *} \mathrm{P}<0.01$, experimental vs. control groups. AngII, angiotensin II; AT1R, AngII type 1 receptor; VEGF, vascular endothelial growth factor; COX-2, cyclooxygenase- 2 .
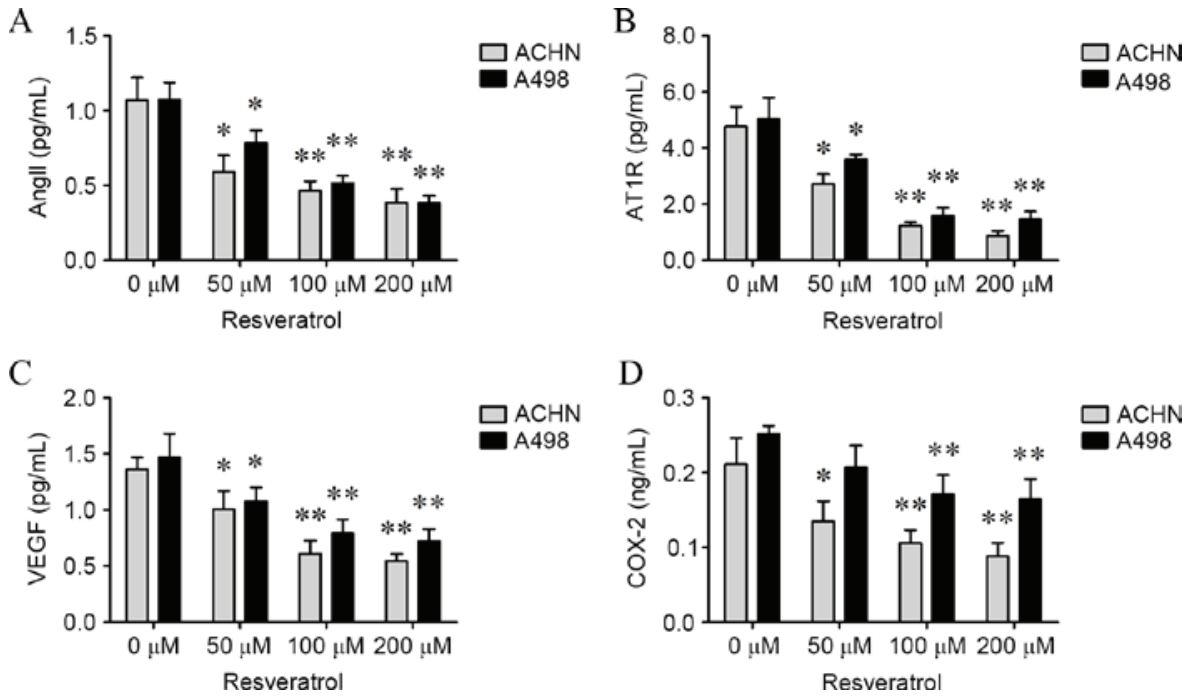

Figure 4. Resveratrol decreased AngII, AT1R, VEGF and COX-2 levels in culture medium for renal carcinoma cells. The levels of (A) AngII, (B) AT1R, (C) VEGF and (D) COX-2 in the culture medium for renal carcinoma cells subsequent to being cultured for $24 \mathrm{~h}$ were determined using enzyme linked immunosorbent assays. " $\mathrm{P}<0.05$ and ${ }^{* *} \mathrm{P}<0.01$, experimental vs. control groups. AngII, angiotensin II; AT1R, AngII type 1 receptor; VEGF, vascular endothelial growth factor; COX-2, cyclooxygenase-2.

ATIR and VEGF may reverse resveratrol-induced renal carcinoma cell growth suppression and apoptosis. To determine whether AngII, AT1R, VEGF and COX-2 may reverse resveratrol-induced renal carcinoma cell regression and apoptosis, cells were incubated with AngII ( $2 \mathrm{pg} / \mathrm{ml})$, AT1R (5 pg/ml), VEGF $(2 \mathrm{pg} / \mathrm{ml})$ or COX-2 $(0.5 \mathrm{ng} / \mathrm{ml})$ when exposed to resveratrol $(100 \mu \mathrm{M})$. AT1R and VEGF were shown to reverse cell growth suppression by resveratrol (AT1R-treatment: RES vs. RES+AT1P, $\mathrm{P}=0.0442$ in ACHN cells and $\mathrm{P}=0.0235$ in A498A cells; VEGF-treatment: RES vs. RES+VEGF, $\mathrm{P}=0.0429$ in ACHN cells and $\mathrm{P}=0.0257$ in A498A cells; Fig. 5A), and cell apoptosis assay indicated a similar result with the cell growth results (AT1R-treatment: RES vs. RES+AT1P, $\mathrm{P}=0.0312$ in ACHN cells and $\mathrm{P}=0.01245$ in A498A cells; VEGF-treatment:
RES vs. RES+VEGF, $\mathrm{P}=0.0351$ in $\mathrm{ACHN}$ cells and $\mathrm{P}=0.0153$ in A498A cells; Fig. 5B). By contrast, AngII and COX-2 played undetected roles of resveratrol-induced cell growth suppression and apoptosis.

\section{Discussion}

As a type of free radical scavenger and antioxidant, resveratrol is recognized as an effective anticancer compound in several types of cancer, such as leukemia (28), breast (29-32), prostate (33) and ovarian cancers (34), melanoma (35) and primary brain tumors (36). In the present study, it was found that resveratrol may suppress renal carcinoma cell growth in a time- and dose-dependent manner. The present study also 
A

a

Angll

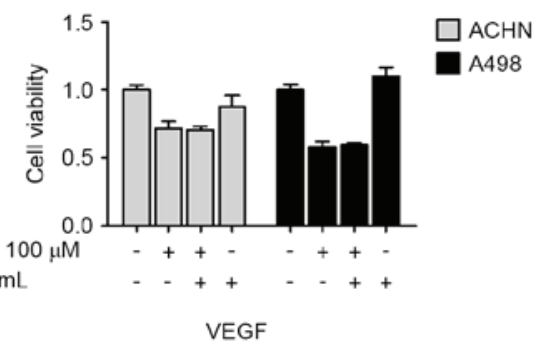

C

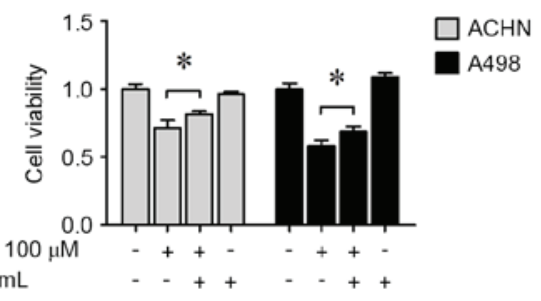

Resveratrol 100
VEGF 2 pg/mL b

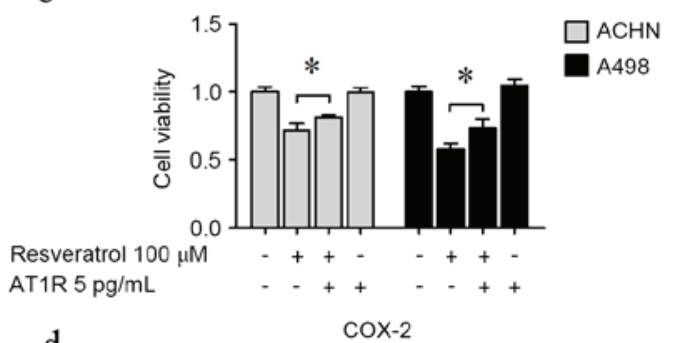

$\mathrm{d}$

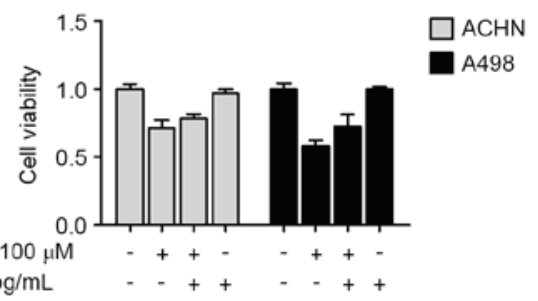

ACHN $\mid$

Ang II
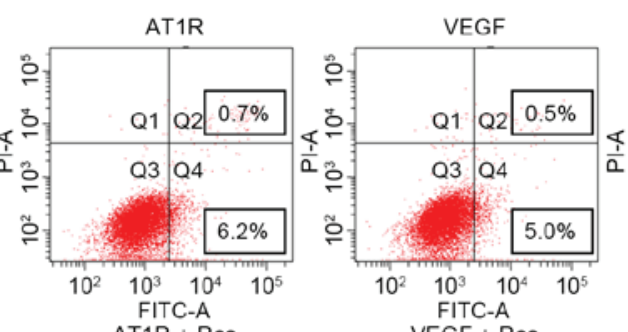

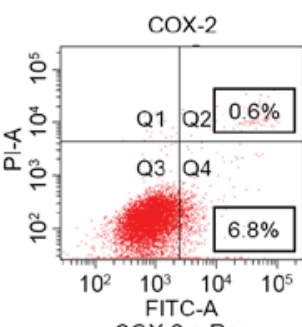
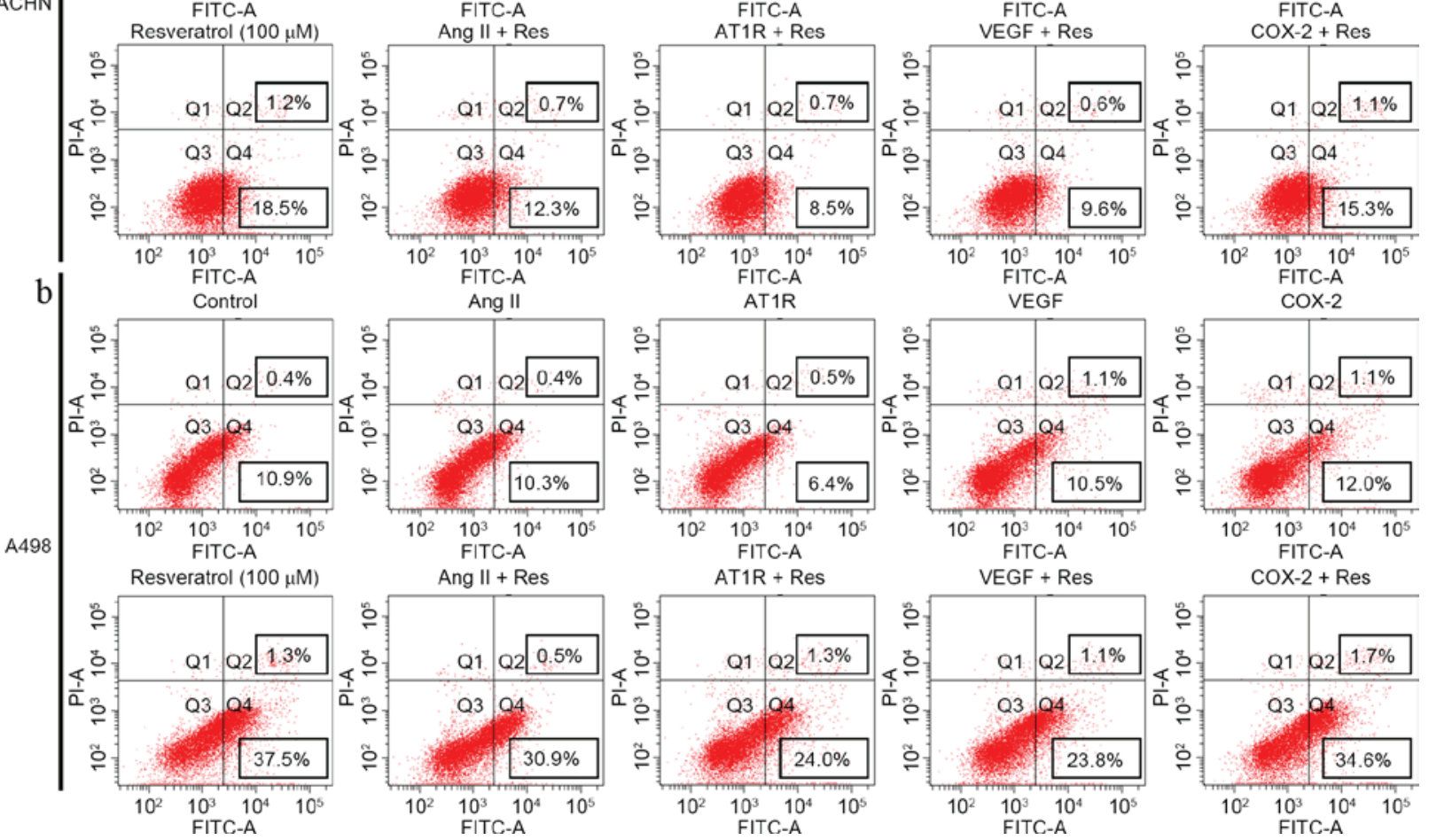

Figure 5. AT1R and VEGF reversed resveratrol-induced cell proliferation inhibition and apoptosis. (A) Resveratrol-induced cell proliferation inhibition in renal carcinoma cells with or without (a) AngII (2 pg/ml), (b) AT1R (5 pg/ml), (c) VEGF (2 pg/ml) and (d) COX-2 (0.5 ng/ml). (B) Apoptosis of (a) ACHN and (b) A498 cells was analyzed according to flow cytometry distributions with or without AngII ( $2 \mathrm{pg} / \mathrm{ml})$, AT1R (5 pg/ml), VEGF (2 pg/ml) and COX-2 $(0.5 \mathrm{ng} / \mathrm{ml}) .{ }^{*} \mathrm{P}<0.05$, experimental vs. control groups. AngII, angiotensin II; AT1R, AngII type 1 receptor; VEGF, vascular endothelial growth factor; COX-2, cyclooxygenase-2; FITC, fluorescein isothiocyanate.

demonstrated that resveratrol induced renal carcinoma cell apoptosis by regulating apoptosis-associated proteins caspase 3/7/9, Bcl-2 and Bax. Reduced AngII, AT1R, VEGF and COX-2 levels were detected subsequent to resveratrol treatment and highlighted the importance of AT1R and VEGF in resveratrol-induced cell apoptosis.
Previously, the renin-angiotensin system (RAS) has been considered to be an endocrine system, and the function of which is limited to regulate blood pressure and electrolyte balance. However, recent studies have detected RAS in several tissues and indicated that local RAS may be involved in regulating a variety of physiological and pathological processes $(7-9,37)$. In 
the RAS, AngII is recognized as a key biological peptide (38), with 2 major specific receptors subtypes, consisting of AT1R and AT2R (39). AngII acting on AT1R has a central role in mediating the majority of the actions of the RAS (16). Studies indicated that RAS was involved in biological activities through the AngII/AT1R pathway (39-41). In the present study, the levels of AngII and AT1R were determined subsequent to resveratrol treatment. The results demonstrated that AngII and AT1R were downregulated in the cells and the culture medium. As VEGF and COX-2 were important downstream regulators in RAS (42-45), it was found that VEGF and COX-2 were inhibited in resveratrol-treated cells and this result is similar to a previous study (29). The present data suggested that RAS suppression would be an important event during resveratrol-induced renal carcinoma cell apoptosis.

RAS was demonstrated to be involved in tumor occurrence and development (46-48). For example, AngII was able to promote epithelial-to-mesenchymal transition in intrahepatic cholangiocarcinoma (38), and angiotensin-converting enzyme inhibitor suppresses growth of colorectal cancer cells (49). AngII was demonstrated to induce VEGF in pancreatic cancer cells through binding AT1R and extracellular signal-regulated kinase 1/2 signaling; in addition, AngII/AT1R may increase expression of VEGF (21). AT1R was identified as upregulated in renal carcinoma and in urogenital cancer in a previous study (40). COX-2 was detected as upregulated in hypoxic conditions and induced angiogenesis through mechanisms distinct from the VEGF axis (25-27). As a type of anti-cancer drug, resveratrol was reported to act via a RAS-dependent pathway (10). In the present study, the effects of AngII, AT1R, VEGF and COX-2 on resveratrol-induced cell growth suppression and apoptosis in renal carcinoma were investigated. It was found that AT1R and VEGF reverse resveratrol-induced renal carcinoma cell growth suppression and apoptosis; however, AngII and COX-2 had no significant effect on resveratrol-induced cell growth suppression and apoptosis. The present results suggest that AT1R and VEGF are the critical factors during resveratrol-induced renal carcinoma cell proliferation suppression and apoptosis.

In summary, the present study examined the effect of resveratrol on renal carcinoma cell growth, suppression and apoptosis and investigated the potential mechanism through RAS. The results indicated that resveratrol may inhibit cell growth, induce apoptosis, and decrease AngII, AT1R, VEGF and COX-2 production in renal carcinoma cells. However, AT1R and VEGF may reverse the functions of resveratrol on renal carcinoma cells. Additional studies should be conducted to demonstrate the exact mechanism underlying the resveratrol-induced cell growth, suppression and apoptosis, which may be, at least partially, through a RAS-associated pathway in renal carcinoma cells.

\section{Acknowledgements}

This study was supported in part by the following grants: Scientific Research Fund of Guangdong Medical College (grant no. M2014019); Science and Technology Planning Project of Guangdong Province (grant no. 2012B031800221); and The National Natural Science Funds (grant no. 81272833) of China.

\section{References}

1. Aggarwal BB, Bhardwaj A, Aggarwal RS, Seeram NP, Shishodia $S$ and Takada Y: Role of resveratrol in prevention and therapy of cancer: Preclinical and clinical studies. Anticancer Res 24: 2783-2840, 2004.

2. Carter LG, D'Orazio JA and Pearson KJ: Resveratrol and cancer: Focus on in vivo evidence. Endocr-Relat Cancer 21: R209-R225, 2014.

3. Ndiaye M, Kumar R and Ahmad N: Resveratrol in cancer management: Where are we and where we go from here? Ann N Y Acad Sci 1215: 144-149, 2011.

4. Reagan-Shaw S, Mukhtar H and Ahmad N: Resveratrol imparts photoprotection of normal cells and enhances the efficacy of radiation therapy in cancer cells. Photochem Photobiol 84: 415-421, 2008

5. Wu ML, Li H, Yu LJ, Chen XY, Kong QY, Song X, Shu XH and Liu J: Short-term resveratrol exposure causes in vitro and in vivo growth inhibition and apoptosis of bladder cancer cells. PLoS One 9: e89806, 2014.

6. Nishimura H: Renin-angiotensin system in vertebrates: Phylogenetic view of structure and function. Anat Sci Int Oct 7, 2016 (Epub ahead of print).

7. Bradshaw AR, Wickremesekera AC, Brasch HD, Chibnall AM, Davis PF, Tan ST and Itinteang T: Glioblastoma multiforme cancer stem cells express components of the renin-angiotensin system. Front Surg 3: 51, 2016.

8. Yoshida T, Kinoshita H, Fukui K, Matsuzaki T, Yoshida K, Mishima T, Yanishi M, Komai Y, Sugi M, Inoue T, et al: Prognostic impact of renin-angiotensin inhibitors in patients with bladder cancer undergoing radical cystectomy. Ann Surg Oncol Oct 11, 2016 (Epub ahead of print).

9. Miyajima A, Yazawa S, Kosaka T, Tanaka N, Shirotake S, Mizuno R, Kikuchi E and Oya M: Prognostic impact of renin-angiotensin system blockade on renal cell carcinoma after surgery. Ann Surg Oncol 22: 3751-3759, 2015.

10. Yang R, Zhang $\mathrm{H}$ and Zhu L: Inhibitory effect of resveratrol on the expression of the VEGF gene and proliferation in renal cancer cells. Mol Med Rep 4: 981-983, 2011.

11. Shirotake S, Miyajima A, Kosaka T, Tanaka N, Kikuchi E, Mikami S, Okada Y and Oya M: Regulation of monocyte chemoattractant protein-1 through angiotensin II type 1 receptor in prostate cancer. Am J Pathol 180: 1008-1016, 2012.

12. Crowley SD and Coffman TM: Recent advances involving the renin-angiotensin system. Exp Cell Res 318: 1049-1056, 2012.

13. Arrieta O,Pineda-Olvera B,Guevara-SalazarP,Hernández-Pedro N, Morales-Espinosa D, Cerón-Lizarraga TL, González-De la Rosa CH, Rembao D, Segura-Pacheco B and Sotelo J: Expression of AT1 and AT2 angiotensin receptors in astrocytomas is associated with poor prognosis. Br J Cancer 99: 160-166, 2008.

14. Li SH, Lu HI, Chang AY, Huang WT, Lin WC, Lee CC, Tien WY, Lan YC, Tsai HT and Chen CH: Angiotensin II type I receptor (AT1R) is an independent prognosticator of esophageal squamous cell carcinoma and promotes cells proliferation via mTOR activation. Oncotarget Aug 24, 2016 (Epub ahead of print).

15. Dolley-Hitze T, Jouan F, Martin B, Mottier S, Edeline J, Moranne O, Le Pogamp P, Belaud-Rotureau MA, Patard JJ, Rioux-Leclercq N and Vigneau C: Angiotensin-2 receptors (AT1-R and AT2-R), new prognostic factors for renal clear-cell carcinoma? Br J Cancer 103: 1698-1705, 2010.

16. Passos-Silva DG, Verano-Braga $T$ and Santos RA: Angiotensin-(1-7): Beyond the cardio-renal actions. Clin Sci (Lond) 124: 443-456, 2013.

17. Ferrara $\mathrm{N}$ and Kerbel RS: Angiogenesis as a therapeutic target. Nature 438: 967-974, 2005.

18. Ferrara N, Gerber HP and LeCouter J: The biology of VEGF and its receptors. Nat Med 9: 669-676, 2003.

19. Cheng YD, Yang H, Chen GQ and Zhang ZC: Molecularly targeted drugs for metastatic colorectal cancer. Drug Des Devel Ther 7: 1315-1322, 2013

20. Ding C, Li L, Yang T, Fan X and Wu G: Combined application of anti-VEGF and anti-EGFR attenuates the growth and angiogenesis of colorectal cancer mainly through suppressing AKT and ERK signaling in mice model. BMC Cancer 16: 791, 2016.

21. Anandanadesan R, Gong Q, Chipitsyna G, Witkiewicz A, Yeo CJ and Arafat HA: Angiotensin II induces vascular endothelial growth factor in pancreatic cancer cells through an angiotensin II type 1 receptor and ERK1/2 signaling. J Gastrointest Surg 12: 57-66, 2008. 
22. Hoellen F, Waldmann A, Banz-Jansen C, Rody A, Heide M, Köster F, Ribbat-Idel J, Thorns C, Gebhard M, Oberländer M, et al: Expression of cyclooxygenase-2 in cervical cancer is associated with lymphovascular invasion. Oncol Lett 12: 2351-2356, 2016.

23. Ali-Fehmi R, Morris RT, Bandyopadhyay S, Che M, Schimp V, Malone JM Jr and Munkarah AR: Expression of cyclooxygenase-2 in advanced stage ovarian serous carcinoma: Correlation with tumor cell proliferation, apoptosis, angiogenesis, and survival. Am J Obstet Gynecol 192: 819-825, 2005

24. Subbaramaiah K and Dannenberg AJ: Cyclooxygenase 2: A molecular target for cancer prevention and treatment. Trends Pharmacol Sci 24: 96-102, 2003.

25. Schmedtje JF Jr, Ji YS, Liu WL, DuBois RN and Runge MS Hypoxia induces cyclooxygenase-2 via the NF-kappaB p65 transcription factor in human vascular endothelial cells. J Biol Chem 272: 601-608, 1997.

26. Lee JJ, Natsuizaka M, Ohashi S, Wong GS, Takaoka M, Michaylira CZ, Budo D, Tobias JW, Kanai M, Shirakawa Y, et al: Hypoxia activates the cyclooxygenase-2-prostaglandin E synthase axis. Carcinogenesis 31: 427-434, 2010.

27. Rüegg C, Dormond $\mathrm{O}$ and Mariotti A: Endothelial cell integrins and COX-2: Mediators and therapeutic targets of tumor angiogenesis. Biochim Biophys Acta 1654: 51-67, 2004.

28. Yaseen A, Chen S, Hock S, Rosato R, Dent P, Dai Y and Grant S: Resveratrol sensitizes acute myelogenous leukemia cells to histone deacetylase inhibitors through reactive oxygen species-mediated activation of the extrinsic apoptotic pathway. Mol Pharmacol 82: 1030-1041, 2012.

29. Singh N, Nigam M, Ranjan V, Zaidi D, Garg VK, Sharma S, Chaturvedi R, Shankar R, Kumar S, Sharma R, et al: Resveratrol as an adjunct therapy in cyclophosphamide-treated MCF-7 cells and breast tumor explants. Cancer Sci 102: 1059-1067, 2011.

30. Shi Y, Yang S, Troup S, Lu X, Callaghan S, Park DS, Xing Y and Yang X: Resveratrol induces apoptosis in breast cancer cells by E2F1-mediated up-regulation of ASPP1. Oncol Rep 25: 1713-1719, 2011.

31. Chottanapund S, Van Duursen MB, Navasumrit P, Hunsonti P, Timtavorn S, Ruchirawat M and Van den Berg M: Anti-aromatase effect of resveratrol and melatonin on hormonal positive breast cancer cells co-cultured with breast adipose fibroblasts. Toxicol In Vitro 28: 1215-1221, 2014

32. Leon-Galicia I, Diaz-Chavez J, Garcia-Villa E, Uribe-Figueroa L, Hidalgo-Miranda A, Herrera LA, Alvarez-Rios E, Garcia-Mena J and Gariglio P: Resveratrol induces downregulation of DNA repair genes in MCF-7 human breast cancer cells. Eur J Cancer Prev 22: 11-20, 2013.

33. Fraser SP, Peters A, Fleming-Jones S, Mukhey D and Djamgoz MB: Resveratrol: Inhibitory effects on metastatic cell behaviors and voltage-gated $\mathrm{Na}^{+}$channel activity in rat prostate cancer in vitro. Nutr Cancer 66: 1047-1058, 2014.

34. Mikula-Pietrasik J, Sosińska P and Książek K: Resveratrol inhibits ovarian cancer cell adhesion to peritoneal mesothelium in vitro by modulating the production of $\alpha 5 \beta 1$ integrins and hyaluronic acid. Gynecol Oncol 134: 624-630, 2014.

35. Chen YJ, Chen YY, Lin YF, Hu HY and Liao HF: Resveratrol inhibits alpha-melanocyte-stimulating hormone signaling, viability, and invasiveness in melanoma cells. Evid Based Complement Alternat Med 2013: 632121, 2013.
36. Wen S, Li H, Wu ML, Fan SH, Wang Q, Shu XH, Kong QY, Chen $\mathrm{XY}$ and Liu J: Inhibition of NF- $\mathrm{kB}$ signaling commits resveratrol-treated medulloblastoma cells to apoptosis without neuronal differentiation. J Neurooncol 104: 169-177, 2011.

37. Magliano DC, Penna-de-Carvalho A, Vazquez-Carrera M, Mandarim-de-Lacerda CA and Aguila MB: Short-term administration of GW501516 improves inflammatory state in white adipose tissue and liver damage in high-fructose-fed mice through modulation of the renin-angiotensin system. Endocrine 50: 355-367, 2015 .

38. Okamoto K, Tajima H, Nakanuma S, Sakai S, Makino I, Kinoshita J, Hayashi H, Nakamura K, Oyama K, Nakagawara H, et al: Angiotensin II enhances epithelial-to-mesenchymal transition through the interaction between activated hepatic stellate cells and the stromal cell-derived factor-1/CXCR4 axis in intrahepatic cholangiocarcinoma. Int J Oncol 41: 573-582, 2012.

39. Kosaka T, Miyajima A, Takayama E, Kikuchi E, Nakashima J, Ohigashi T, Asano T, Sakamoto M, Okita H, Murai M and Hayakawa M: Angiotensin II type 1 receptor antagonist as an angiogenic inhibitor in prostate cancer. Prostate 67: 41-49, 2007.

40. Miyajima A, Kikuchi E, Kosaka T and Oya M: Angiotensin II type 1 receptor antagonist as an angiogenic inhibitor in urogenital cancer. Rev Recent Clin Trials 4: 75-78, 2009.

41. Miyajima A, Kosaka T, Asano T, Seta K, Kawai T and Hayakawa M: Angiotensin II type I antagonist prevents pulmonary metastasis of murine renal cancer by inhibiting tumor angiogenesis. Cancer Res 62: 4176-4179, 2002.

42. de Haas S, Delmar P, Bansal AT, Moisse M, Miles DW, Leighl N, Escudier B, Van Cutsem E, Carmeliet P, Scherer SJ, et al: Genetic variability of VEGF pathway genes in six randomized phase III trials assessing the addition of bevacizumab to standard therapy. Angiogenesis 17: 909-920, 2014.

43. Mittal K, Koon H, Elson P, Triozzi P, Dowlati A, Chen H, Borden EC and Rini BI: Dual VEGF/VEGFR inhibition in advanced solid malignancies: Clinical effects and pharmacodynamic biomarkers. Cancer Biol Ther 15: 975-981, 2014.

44. Chang WS, Liao CH, Miao CE, Wu HC, Hou LL, Hsiao CL, Ji HX, Tsai CW and Bau DT: The role of functional polymorphisms of cyclooxygenase 2 in renal cell carcinoma. Anticancer Res 34: 5481-5486, 2014.

45. He W, Zhang M, Zhao M, Davis LS, Blackwell TS, Yull F, Breyer MD and Hao CM: Increased dietary sodium induces COX2 expression by activating NFkB in renal medullary interstitial cells. Pflugers Arch 466: 357-367, 2014.

46. Fan L, Feng Y, Wan HY, Ni L, Qian YR, Guo Y, Xiang Y and Li QY: Hypoxia induces dysregulation of local renin-angiotensin system in mouse Lewis lung carcinoma cells. Genet Mol Res 13: 10562-10573, 2014

47. Ino K, Shibata K, Kajiyama H, Nawa A, Nomura S and Kikkawa F: Manipulating the angiotensin system-new approaches to the treatment of solid tumours. Expert Opin Biol Ther 6: 243-255, 2006.

48. Araújo WF, Naves MA, Ravanini JN, Schor N and Teixeira VP: Renin-angiotensin system (RAS) blockade attenuates growth and metastatic potential of renal cell carcinoma in mice. Urol Oncol 33: 389.e1-e7, 2015.

49. Childers WK: Interactions of the renin-angiotensin system in colorectal cancer and metastasis. Int J Colorectal Dis 30: 749-752, 2015. 